INTIQAD: JURNAL AGAMA DAN PENDIDIKAN ISLAM

ISSN 1979-9950 (print) || ISSN 2598-0033 (online), http://jurnal.umsu.ac.id/index.php/intiqad DOI: https://doi.org/10.30596/intiqad.v10i1.1925

Published June 2018

\section{Pengaruh Pengelolaan Kelas Terhadap Kemampuan Pemahaman dan Hasil Belajar Siswa Kelas VII MTs Negeri 2 Medan}

\author{
Muhammad Arif Hidayat
}

Sekolah Tinggi Agama Islam Jam'iyah Mahmudiyah

Email : rudi.habibie93@gmail.com 


\section{INTIQAD: JURNAL AGAMA DAN PENDIDIKAN ISLAM}

ISSN 1979-9950 (print) || ISSN 2598-0033 (online), http://jurnal.umsu.ac.id/index.php/intiqad DOI: https://doi.org/10.30596/intiqad.v10i1.1925

Published June 2018

pembelajaran dengan pendekatan pengelolaan kelas lebih aktif dalam belajar, terutama berdiskusi dengan temannya, dan juga siswa lebih berani mengemukakan atau mengajukan pertanyaaan kepada guru, serta lebih kreatif dalam menyelesaikan permasalahan yang di berikan.

Keyword: Pengelolaan Kelas, Pemahaman, Hasil Belajar, Siswa.

\section{A. Pendahuluan}

Mendidik merupakan suatu aktifitas yang memiliki tujuan yang hendak di capai. Dalam suatu sistem pendidikan, mendidik berada dalam suatu proses yang berkesinambungan pada setiap jenis dan jenjang pendidikan. Tugas guru dalam menyampaikan materi pelajaran hendaknya mampu menciptakan suasana kelas yang menyenangkan. Suasana kelas yang menyenangkan mampu memberi semangat kepada siswa untuk belajar. Guru tidak sekedar menyampaikan materi pelajaran kepada siswa, tetapi juga bagaimana menyiapkan mereka menjadi manusia yang terampil dan siap menghadapi tantangan global yang terjadi di masa depan. ${ }^{1}$

Seorang guru hendaknya mampu mengarahkan dan membimbing siswa

1 Nofisaky, Strategi Proses Pembelajaran, (Bandung: Azalea, 2016), h.5. untuk aktif dalam kegiatan belajar mengajar, sehingga tercipta suasana serta interaksi yang baik antara guru dengan siswa maupun siswa dengan siswa. Keaktifan serta terjadinya perubahan perilaku yang selaras dengan tujuan pengajaran yang hendak di capai merupakan suatu hal yang menandai terjadinya proses pembelajaran. Selain itu, guru menjadi faktor yang berpengaruh terhadap hasil belajar siswa di sekolah hendaknya menguasai keterampilan mengajar dan menerapkannya dalam proses belajar mengajar. Salah satu keterampilan yang harus di miliki guru adalah keterampilan mengelola kelas mengingat tugas guru di dalam kelas adalah membelajarkan siswa dengan menyediakan kondisi belajar yang optimal, sesuai tujuan pengajaran yang hendak di capai. ${ }^{2}$

2 Putri Ayu Hapsari, Pembelajaran : Teori dan Praktik, (Yogyakarta: Mutiara Press, 2016), h.10. 


\section{INTIQAD: JURNAL AGAMA DAN PENDIDIKAN ISLAM}

ISSN 1979-9950 (print) || ISSN 2598-0033 (online), http://jurnal.umsu.ac.id/index.php/intiqad DOI: https://doi.org/10.30596/intiqad.v10i1.1925

Published June 2018

Menurut Suharsimi Arikunto dalam Syaiful Bahri Djamarah, “... pengelolaan kelas adalah suatu usaha yang di lakukan oleh penanggung jawab kegiatan belajar mengajar atau membantu dengan maksud agar di capai kondisi optimal sehingga dapat terlaksana kegiatan belajar seperti yang di harapkan."3 Penanggung jawab kegiatan belajar mengajar yang di maksud adalah guru. Untuk tercapainya tujuan pembelajaran perlu adanya tindakan yang dapat mewujudkan terciptanya suasana kelas yang optimal. Pengelolaan kelas di lihat dari dua segi yaitu pengelolaan yang menyangkut siswa (pengaturan siswa) dan pengelolaan secara fisik. Pengelolaan fisik yang berupa ruangan, perabot serta alat pelajaran. ${ }^{4}$

Sri Anitah Wiryawan dan Noorhadi dalam Tri Mulyani W, menyatakan bahwa pengelolaan kelas merupakan suatu kegiatan pengaturan siswa dan pengaturan fisik kelas sehingga kegiatan pembelajaran dapat berjalan dengan lancar atau terciptanya

3 Syaiful Bahri Djamarah, Prestasi Belajar dan Kompetensi Guru, (Surabaya: Usaha Nasional, 2009), h.198.

4 Renata, Teori Belajar, (Jakarta: Insan Press, 2016), h.20. suasana belajar yang optimal bagi berlangsungnya kegiatan belajar siswa yang efektif. Pengelolaan kelas merupakan salah satu keterampilan guru dalam menciptakan dan memelihara kondisi belajar yang optimal dan mengembalikannya bila terjadi gangguan dalam proses belajar mengajar. Maksud dari gangguan selama proses pembelajaran yaitu siswa yang gaduh selama pembelajaran berlangsung, siswa mengganggu siswa yang lain, mengantuk saat mengikuti pembelajaran. Guru yang berperan sebagai pengelola kelas, hendaknya dapat menyediakan fasilitas yang memungkinkan kemudahan kegiatan belajar siswa, dan lingkungan belajar yang menyenangkan siswa sehingga siswa dapat mengikuti kegiatan belajar mengajar dengan aman dan nyaman. ${ }^{5}$

Menurut Syaiful Bahri Djamarah \& Aswan Zain menyatakan bahwa pengelolaan kelas di lakukan untuk menciptakan lingkungan belajar yang kondusif bagi siswa sehingga tercapai tujuan pembelajaran yang efektif dan

5 Tri Mulyani, W, Pengelolaan Kelas : Classroom Management, (Yogyakarta: Fakultas Ilmu Pendidikan Universitas Negeri Yogyakarta, 2001), h.24. 


\section{INTIQAD: JURNAL AGAMA DAN PENDIDIKAN ISLAM}

ISSN 1979-9950 (print) || ISSN 2598-0033 (online), http://jurnal.umsu.ac.id/index.php/intiqad DOI: https://doi.org/10.30596/intiqad.v10i1.1925

Published June 2018

efisien. Penciptaan lingkungan belajar dapat di lakukan dengan menata kondisi kelas agar siswa lebih antusias dalam mengikuti pembelajaran. Penataan kelas termasuk dalam pengelolaan kelas secara fisik. Pengelolaan kelas secara fisik berupa pengaturan ruang kelas yang meliputi pengaturan tempat duduk, pengaturan alat-alat pengajaran, penataan keindahan dan kebersihan kelas serta ventilasi dan tata cahaya. ${ }^{6}$

Berdasarkan hasil observasi pada bulan Oktober sampai dengan Nopember 2017 di Madrasah Tsanawiyah Negeri 2 Medan peneliti mendapatkan suatu deskripsi bahwa pengelolaan kelas yang di lakukan oleh guru belum di lakukan secara maksimal. Ketika kegiatan belajar mengajar berlangsung, guru masih melaksanakan pembelajaran dengan suasana kelas yang monoton, belum ada variasi dalam kegiatan belajar mengajar. Ketika kegiatan belajar mengajar berlangsung sudah ada kontrol dari guru, hanya saja lebih terfokus pada pengaturan siswa berupa tindakan korektif, sedangkan pengelolaan fisik belum di lakukan,

${ }^{6}$ Syaiful Bahri Djamarah dan Aswin Zain, Strategi Belajar Mengajar, (Jakarta: Rineka Cipta, 2002), h.227-230. misalnya guru tidak membuka jendela agar terjadi sirkulasi udara yang baik. Jika ada siswa yang berjalan-jalan di kelas saat pembelajaran berlangsung, guru tidak langsung memberikan tindakan berupa teguran pada siswa. Kelas yang gaduh akan mempengaruhi konsentrasi siswa dalam mengikuti pembelajaran. Guru harus lebih tanggap terhadap situasi serta kondisi di kelas agar suasana kelas yang kondusif tetap terjaga. Selain sikap tanggap seorang guru terhadap situasi di kelas, guru juga harus mampu membagi perhatian pada saat di lakukan kegiatan yang berlangsung pada waktu yang sama (tidak terfokus pada satu siswa/kelompok). Selanjutnya, siswa kelas VII memiliki nilai Kriteria Ketuntasan Minimal yang masih di bawah $75 \%$. Yang memiliki Kriteria Ketuntasan Minimal $\geq 75 \%$ tergolong dalam persentase sebesar $25 \%$ atau dalam jumlah siswa sebesar 22 orang siswa yang lulus pada Kriteria Ketuntasan Minimal. Dan selebihnya pada jumlah 18 orang siswa masih pada kriteria $<75 \%$. Hal ini di karenakan siswa dalam proses pembelajaran masih dalam situasi yang tidak kondusif. Guru yang masuk pada kelas tersebut, tidak 


\section{INTIQAD: JURNAL AGAMA DAN PENDIDIKAN ISLAM}

ISSN 1979-9950 (print) || ISSN 2598-0033 (online), http://jurnal.umsu.ac.id/index.php/intiqad DOI: https://doi.org/10.30596/intiqad.v10i1.1925

Published June 2018

secara optimal memberikan pengelolaan kelas pada saat memberikan materi pelajaran. Masih banyak para siswa yang bermain smartphone dalam kelas, berbicara, bermain dalam kelas, mengantuk dan mengganggu para siswa lain yang sedang belajar. Maka dengan deskripsi masalah yang di temukan di lapangan, perlu adanya suatu pengelolaan kelas yang baik agar para siswa dapat memenuhi Kriteria Ketuntasan Minimal. ${ }^{7}$

Hasil yang di peroleh siswa dalam mengikuti proses pembelajaran di kelas merupakan salah satu tolak ukur keberhasilan siswa di sekolah. Hasil belajar yang di maksud adalah tingkat pencapaian hasil yang telah di capai siswa berupa pengetahuan, pemahaman dan penerapan. Jadi dapat di katakan bahwa Hasil siswa merupakan hasil belajar siswa yang di peroleh selama proses kegiatan belajar mengajar.

Untuk memperoleh kegiatan belajar mengajar yang optimal, maka di perlukan pengelolaan kelas yang efektif.

7 Hasil observasi dan wawancara dengan Guru Quran Hadis Madrasah Tsanawiyah Negeri 2 Medan kelas VII pada tanggal 09 Oktober 2017 dan tanggal 06 Nopember 2017 pukul 08.30 sampai dengan 09.30 WIB.
Pengelolaan kelas yang efektif akan menghasilkan pengajaran yang efektif pula. Untuk menciptakan pengajaran yang efektif dapat di lakukan dengan melakukan kegiatan-kegiatan yang dapat menciptakan serta mengkondisikan kelas yang optimal bagi terjadinya proses belajar mengajar, antara lain: penghentian tingkah laku siswa yang mengganggu perhatian kelas, pemberian penghargaan kepada siswa yang menyelesaikan tugas dengan tepat waktu, hubungan/interaksi yang baik antar guru dengan siswa maupun siswa dengan siswa, dan mampu mengatur siswa serta mengendalikannya sehingga tercipta suasana yang menyenangkan selama proses pembelajaran berlangsung. ${ }^{8}$ Pengelolaan kelas yang di lakukan oleh guru memegang peranan penting dalam menanamkan motivasi pada siswa untuk terus berHasil. Dengan adanya pengelolaan kelas yang efektif dan optimal, baik yang di lakukan oleh guru maupun wali kelas dapat memberikan pengaruh terhadap Hasil belajar siswa secara keseluruhan.

${ }^{8}$ Syaiful Bahri Djamarah dan Aswin Zain, ...., h.194-196. 


\section{INTIQAD: JURNAL AGAMA DAN PENDIDIKAN ISLAM}

ISSN 1979-9950 (print) || ISSN 2598-0033 (online), http://jurnal.umsu.ac.id/index.php/intiqad DOI: https://doi.org/10.30596/intiqad.v10i1.1925

Published June 2018

Menurut Suharsimi Arikunto dalam Syaiful Bahri Djamarah \& Aswan Zain, yang termasuk dalam pengelolaan kelas secara fisik dapat di lakukan dengan membuka jendela agar udara segar dapat masuk ke ruangan atau agar ruangan menjadi terang, menyalakan lampu listrik, menggeser papan tulis maupun mengatur meja. Dengan begitu, peneliti melakukan pengelolaan kelas secara fisik dengan cara: mengatur tempat duduk siswa, menata ruangan kelas, mengatur waktu dan media pembelajaran, dan penciptaan disiplin kelas. Untuk pengaturan siswa berupa tindakan pencegahan/preventif dan tindakan korektif. Sedangkan kelompok kontrol merupakan kelas yang di beri perlakuan pengelolaan kelas berupa pengaturan siswa. Guru melaksanakan proses pembelajaran dengan penerapan pengelolaan kelas yang biasa di lakukan selama pembelajaran sebelumnya (biasa di lakukan sehari-hari). ${ }^{9}$

Proses pembelajaran mata pelajaran Quran Hadis akan lebih mudah di pahami oleh siswa jika menggunakan media pembelajaran yang

${ }^{9}$ Syaiful Bahri Djamarah dan Aswin Zain, ...., h.199. lebih nyata dan sering di lihat maupun di dengar oleh siswa. Selain media yang di gunakan, pengaturan tempat duduk siswa serta berbagai tindakan yang di lakukan selama proses pembelajaran berlangsung juga mempengaruhi tingkat pemahaman siswa. Berdasarkan hal yang di lakukan oleh guru tersebut merupakan salah satu kegiatan yang di lakukan dalam mengelola kelas dan di gunakan sebagai solusi atas permasalahan yang ada di kelas. ${ }^{10}$

Selain dari mata pelajaran, suasana yang kurang kondusif juga terlihat dari adanya sebagian siswa yang mengantuk dan mengganggu siswa yang lain saat proses kegiatan belajar mengajar berlangsung. Kurangnya interaksi yang terjadi antar guru dengan siswa, juga mempengaruhi keterlibatan serta antusias siswa dalam mengikuti pelajaran. Situasi tersebut terjadi karena siswa merasa bosan dan tidak memiliki ketertarikan untuk mengikuti pelajaran dengan baik dan bersemangat. ${ }^{11}$

\section{B. Tinjauan Pustaka}

10 Nofisaky, Pendidikan Agama Islam : Teori dan Praktik, (Jakarta: Lentera Ilmu, 2015), h.55.

11 Muhammad Zuhri, Pembelajaran di Kelas dalam Persepektif Sosial, (Jakarta: CV Kenanga Indah, 2015), h.78. 


\section{INTIQAD: JURNAL AGAMA DAN PENDIDIKAN ISLAM}

ISSN 1979-9950 (print) || ISSN 2598-0033 (online), http://jurnal.umsu.ac.id/index.php/intiqad DOI: https://doi.org/10.30596/intiqad.v10i1.1925

Published June 2018

\section{Pengertian Pengelolaan Kelas}

Secara istilah, pengelolaan kelas berasal dari bahasa Inggris "Classroom Management". Classroom berarti kelas sedangkan Management berarti kepemimpinan, ketatalaksanaan, penguasaan maupun pengurusan. ${ }^{12}$ Secara umum dari segi didaktis menurut Sri Anitah Wiryawan dan Noorhadi dalam Tri Mulyani, kelas di artikan sebagai sekelompok siswa yang pada waktu yang sama menerima pelajaran yang sama dari guru yang sama. ${ }^{13}$

Pengelolaan kelas di artikan sebagai kepemimpinan ataupun ketatalaksanaan guru dalam praktek penyelenggaraan kelas. $^{14}$ Sependapat dengan hal tersebut Moh. Uzer Usman mengemukakan bahwa "Pengelolaan kelas adalah keterampilan guru untuk menciptakan dan memelihara kondisi belajar yang optimal dan mengembalikannya bila terjadi

12 Nofisaky, Pengelolaan Kelas : Teori dan Praktik, (Jakarta: Universitas Negeri Jakarta, 2016), h.5.

13 Tri Mulyani, W, Pengelolaan Kelas : Classroom Management, (Yogyakarta: Fakultas Ilmu Pendidikan Universitas Negeri Yogyakarta, 2001), h.6.

${ }^{14}$ Tri Mulyani, W, ...., h.5. gangguan dalam proses belajar mengajar". ${ }^{15}$

Menurut Djauzak Ahmad dalam Haryanto, dkk, berpendapat bahwa pengelolaan kelas adalah usaha menciptakan kelas agar terwujud suasana belajar mengajar yang efektif dan menyenangkan serta dapat memotivasi siswa untuk belajar dengan baik sesuai kemampuannya. ${ }^{16}$

Penerapan pengelolaan kelas harus di lakukan dengan baik agar tercapai tujuan yang di inginkan. Pengelolaan kelas pada kelompok eksperimen yaitu dengan menerapkan kedua jenis pengelolaan kelas baik secara fisik maupun pengaturan siswa. Pengelolaan kelas secara fisik dilakukan mengatur tempat duduk siswa, menata ruangan kelas, mengatur waktu dan media pembelajaran, dan penciptaan disiplin kelas, sedangkan untuk pengaturan siswa di lakukan dengan 2 langkah yaitu: (a) tindakan

${ }^{15}$ Mohammad Uzer Usman, Menjadi Guru Profesional, (Bandung: PT. Remaja Rosdakarya, 2006), h.97.

16 Haryanto, dkk, Strategi Belajar Mengajar, (Yogyakarta: Fakultas Ilmu Pendidikan Universitas Negeri Yogyakarta, 2003), h.81. 


\section{INTIQAD: JURNAL AGAMA DAN PENDIDIKAN ISLAM}

ISSN 1979-9950 (print) || ISSN 2598-0033 (online), http://jurnal.umsu.ac.id/index.php/intiqad DOI: https://doi.org/10.30596/intiqad.v10i1.1925

Published June 2018

pencegahan/preventif dan (b) tindakan korektif. ${ }^{17}$

Pengelolaan kelas yang efektif merupakan prasyarat mutlak bagi terjadinya proses belajar mengajar yang efektif. ${ }^{18}$ Berdasarkan pernyataan tersebut, dalam suatu pembelajaran di perlukan adanya pengelolaan kelas yang efektif serta optimal. Pengelolaan kelas yang di lakukan bukan hanya pengelolaan kelas secara fisik melainkan pengelolaan kelas dengan pengaturan siswa.

\section{Tujuan Pengelolaan Kelas}

Pengelolaan kelas di lakukan agar suasana belajar di kelas tetap menyenangkan. Adapun tujuan pengelolaan kelas menurut Sudirman dalam Syaiful Bahri Djamarah dan Aswan Zain, adalah penyediaan fasilitas bagi bermacam-macam kegiatan belajar siswa dalam lingkungan sosial, emosional, dan intelektual dalam kelas. Fasilitas yang di sediakan tersebut akan berpengaruh pada terciptanya suasana sosial yang memberikan kepuasan, suasana disiplin, dan perkembangan

${ }^{17}$ Tri Mulyani, W, ...., h.6.

18 Syaiful Bahri Djamarah dan Aswan Zain, Strategi Belajar Mengajar, (Jakarta: Rineka Cipta, 2002), h.195. intelektual. ${ }^{19}$ Selain tujuan pengelolaan kelas tersebut, Suharsimi Arikunto dalam Syaiful Bahri Djamarah dan Aswan Zain, berpendapat bahwa pengelolaan kelas bertujuan agar setiap anak di kelas dapat bekerja dengan tertib sehingga dapat tercapai tujuan pengajaran secara efektif dan efisien. ${ }^{20}$

Berbagai tujuan pengelolaan kelas tersebut, merujuk pada penciptaan kondisi belajar yang efektif dan menyenangkan. Kondisi kelas tersebut mampu menunjang semangat siswa dalam mengikuti pembelajaran. Siswa yang memiliki semangat yang tinggi dalam mengikuti pembelajaran, akan berpengaruh terhadap pemahaman serta Hasil belajar siswa.

Agar tujuan dari pengelolaan kelas tersebut dapat terwujud, maka dalam penelitian ini, peneliti menerapkan pengelolaan kelas yang efektif dan optimal dengan menciptakan suasana kelas yang menyenangkan, sehingga siswa akan merasa nyaman serta lebih berkonsentrasi selama proses pembelajaran berlangsung.

\footnotetext{
19 Syaiful Bahri Djamarah dan Aswan Zain, ...., h.199.

20 Syaiful Bahri Djamarah dan Aswan Zain, ...., h.200.
} 


\section{INTIQAD: JURNAL AGAMA DAN PENDIDIKAN ISLAM}

ISSN 1979-9950 (print) || ISSN 2598-0033 (online), http://jurnal.umsu.ac.id/index.php/intiqad DOI: https://doi.org/10.30596/intiqad.v10i1.1925

Published June 2018

\section{Prinsip-Prinsip}

\section{Pengelolaan}

\section{Kelas}

Dalam suatu kelas terdapat berbagai permasalahan yang sering timbul. Guna mengurangi permasalahan tersebut, guru haruslah memiliki prinsip pengelolaan kelas. Menurut Aswan Zain dalam Haryanto, dkk, mengemukakan bahwa prinsip-prinsip pengelolaan kelas meliputi: a) Prinsip hangat dan antusias; b) Prinsip tantangan; c) Prinsip bervariasi; d) Prinsip keluwesan; e) Prinsip disiplin diri; dan f) Penekanan pada hal-hal yang positif. $^{21}$

Sedangkan menurut Mulyani Sumantri dan Johar Permana mengemukakan bahwa prinsip-prinsip pengelolaan kelas meliputi : a) Kehangatan dan keantusiasan; b) Tantangan, gunakan kata-kata, tindakan, atau bahan dengan sajian yang menantang; c) Bervariasi, gunakan variasi dalam proses belajar mengajar; d) Keluwesan, di gunakan apabila guru mendapatkan hambatan dalam perilaku peserta didik, sehingga guru dapat merubah strategi mengajarnya; e) Menekankan hal-hal positif, memelihara hal positif dan menghindari konsentrasi pada hal negatif; dan f) Tanamkan

\footnotetext{
${ }^{21}$ Haryanto, dkk., ...., h.89.
}

disiplin diri; selalu mendorong peserta didik agar memiliki disiplin diri. ${ }^{22}$

Prinsip tersebut di gunakan agar suasana di kelas serta interaksi yang terjadi antara guru dengan siswa maupun siswa dengan siswa dapat berjalan dengan baik. Selain itu, berbagai prinsip pengelolaan kelas mampu menciptakan rasa nyaman bagi siswa selama mengikuti proses pembelajaran.

Dalam penelitian ini, peneliti menggunakan semua prinsip pengelolaan kelas. Hal ini bertujuan agar lebih mudah melakukan pengelolaan kelas serta mempererat interaksi antar guru dengan siswa. Selain itu dengan penggunaan prinsip pengelolaan kelas di harapkan mampu memberikan pengaruh positif bukan hanya bagi perilaku siswa melainkan juga pada Hasil belajar siswa.

Selama proses pengelolaan kelas berlangsung, guru di harapkan menghindari hal-hal berikut, antara lain: a) Campur tangan yang berlebihan; b) Kesenyapan; c) Ketidaktepatan

22 Mulyani Sumantri dan Johar Permana, Strategi Belajar Mengajar, (Yogyakarta: Dirjen Pendidikan Tinggi, 1999). 


\section{INTIQAD: JURNAL AGAMA DAN PENDIDIKAN ISLAM}

ISSN 1979-9950 (print) || ISSN 2598-0033 (online), http://jurnal.umsu.ac.id/index.php/intiqad DOI: https://doi.org/10.30596/intiqad.v10i1.1925

Published June 2018

memulai dan mengakhiri kegiatan; d) Penyimpangan; e) Bertele-tele; dan f) Pengulangan penjelasan yang tidak perlu. $^{23}$

Pengelolaan kelas yang efektif mampu menciptakan kondisi kelas yang efektif. Kondisi kelas yang efektif akan menimbulkan suasana yang menyenangkan serta menghindari timbulnya rasa bosan pada siswa. Siswa akan merasa bosan jika melalui beberapa menit waktu luang tanpa adanya kegiatan (kesenyapan) yang menyenangkan maupun menciptakan semangat siswa. Selain itu campur tangan guru yang berlebihan misalnya guru kurang memberikan kesempatan pada siswa untuk aktif dalam pembelajaran, akan membuat siswa merasa terkekang serta menghambat siswa dalam menyampaikan pendapat di depan kelas. Selain itu, selama proses peembelajaran haruslah di lakukan secara sistematis agar tidak terjadi pengulangan materi. Keruntutan penyampaian materi akan mempengaruhi pemahaman siswa mengenai materi yang di pelajari. Maka

\footnotetext{
${ }^{23}$ Haryanto, dkk., ...., h.92.
}

dengan pengelolaan kelas, sistem pembelajaran juga akan lebih baik. ${ }^{24}$

\section{Pengertian Hasil Belajar}

Hasil belajar adalah sebuah kalimat yang terdiri dari dua kata, yakni Hasil dan belajar. Untuk memahami lebih jauh tentang pengertian Hasil belajar, peneliti menjabarkan makna dari kedua kata tersebut.

$$
\text { Menurut Syaiful Bahri }
$$

Djamarah, menyatakan bahwa Hasil adalah apa yang telah dapat di ciptakan, hasil pekerjaan, hasil yang menyenangkan hati yang di peroleh dengan jalan keuletan kerja. ${ }^{25}$ Nasrun Harahap dalam Syaiful Bahri Djamarah, berpendapat bahwa Hasil adalah penilaian pendidikan tentang perkembangan dan kemajuan siswa berkenaan dengan penguasaan bahan pelajaran yang di sajikan kepada siswa. Dari pengertian tersebut dapat di ambil kesimpulan bahwa Hasil adalah hasil dari suatu kegiatan seseorang atau kelompok yang telah di kerjakan, di

${ }^{24}$ Nofisaky., ...., h.10.

25 Syaiful Bahri Djamarah, Prestasi Belajar dan Kompetensi Guru, (Surabaya: Usaha Nasional, 1994), h.20-21. 


\section{INTIQAD: JURNAL AGAMA DAN PENDIDIKAN ISLAM}

ISSN 1979-9950 (print) || ISSN 2598-0033 (online), http://jurnal.umsu.ac.id/index.php/intiqad DOI: https://doi.org/10.30596/intiqad.v10i1.1925

Published June 2018

ciptakan dan menyenangkan hati yang di peroleh dengan jalan bekerja. ${ }^{26}$

Belajar adalah aktifitas yang menghasilkan perubahan pada diri individu yang belajar, baik aktual maupun potensial. Menurut Thorndike dalam Asri Budiningsih, belajar merupakan suatu proses interaksi antara stimulus dengan respon. Seseorang yang telah mengalami proses belajar akan mengalami perubahan tingkah laku baik berwujud konkret (dapat di amati), maupun berwujud abstrak (tidak dapat di amati). ${ }^{27}$ Belajar adalah proses berubahnya tingkah laku siswa melalui pengalaman yang di perolehnya. Pengalaman tersebut dapat di peroleh melalui melihat, mengamati serta memahami sesuatu. ${ }^{28}$

Menurut Hilgard dalam Nana Syaodih Sukmadinata, belajar adalah suatu proses di mana suatu perilaku muncul atau berubah karena adanya

22.

26 Syaiful Bahri Djamarah, ...., h.21-

27 Asri Budiningsih, C. (2002). Belajar dan Pembelajaran, Yogyakarta: Fakultas Ilmu Pendidikan Universitas Negeri Yogyakarta, h.18.

28 Nana Sudjana, Dasar-Dasar Proses Belajar Mengajar, (Bandung: Sinar Baru Aldesindo,2005), h.28-29. respons terhadap suatu situasi. ${ }^{29}$ Sedangkan pengertian belajar menurut Slameto menyatakan bahwa belajar ialah suatu usaha yang di lakukan seseorang untuk memperoleh suatu perubahan tingkah laku yang baru secara keseluruhan, sebagai hasil pengalamannya sendiri dalam interaksi dengan lingkungannya. ${ }^{30}$ Muhhibbin Syah mengatakan bahwa belajar adalah tahapan perubahan seluruh tingkah laku individu yang relatif menetap sebagai hasil pengalaman dan interaksi dengan lingkungan yang melibatkan proses kognitif. ${ }^{31}$

\section{Kemampuan Pemahaman}

Pemahaman sebagai terjemahan dari istilah understanding di artikan sebagai penyerapan arti suatu materi bahan yang di pelajari ${ }^{32}$. Menurut Michener dalam Sumarmo, untuk

29 Nana Syaodih Sukmadinata. (2005). Landasan Psikologi Proses Pendidikan, Bandung: PT Remaja Rosdakarya, h.156.

30 Slameto, Belajar dan FaktorFaktor Yang Mempengaruhinya. Edisi Revisi, (Jakarta: PT Rineka Cipta, 2003), h. 2 .

31 Muhhibbin Syah, Psikologi Pendidikan, (Bandung: PT Remaja Rosdakarya, 2010), h.136.

32 Nofisaky. (2016). Belajar : Teori dan Praktik, Jakarta: CV Lautan Ilmu, h.35. 


\section{INTIQAD: JURNAL AGAMA DAN PENDIDIKAN ISLAM}

ISSN 1979-9950 (print) || ISSN 2598-0033 (online), http://jurnal.umsu.ac.id/index.php/intiqad DOI: https://doi.org/10.30596/intiqad.v10i1.1925

Published June 2018

memahami suatu objek secara mendalam seseorang harus mengetahui: 1) Objek itu sendiri; 2) Relasinya dengan objek lain yang sejenis; 3) Relasinya dengan objek lain yang tidak sejenis; 4) Relasi dual dengan objek lainnya yang sejenis; dan 5) Relasi dengan objek dalam teori lainnya. ${ }^{33}$

\section{Selanjutnya Skemp dalam}

Sumarmo, membedakan dua jenis pemahaman konsep yaitu pemahaman instrumental dan pemahaman relasional. Pemahaman instrumental di artikan sebagai pemahaman konsep yang saling terpisah dan hanya hafal konsep dalam teori sederhana. Dalam hal ini seseorang hanya memahami urutan pengerjaan atau langkah kerja. Sebaliknya pada pemahaman relasional termuat skema atau struktur yang dapat di gunakan pada penyelesaian masalah yang lebih luas dan sifat pemakaiannya lebih bermakna. ${ }^{34}$

33 Sumarmo, U, Kemampuan Pemahaman dan Penalaran Siswa SMA di kaitkan dengan Kemampuan Penalaran Logik Siswa dan Beberapa Unsur Proses Belajar Mengajar. (Disertasi Doktor pada Universitas Islam Negeri Sunan Gunung Djati Bandung: tidak diterbitkan, 1987), h.24.

${ }^{34}$ Sumarmo, U,..., h.24.
Pemahaman merupakan salah satu aspek dalam Taksonomi Bloom pada ranah kognitif. Bloom dalam membagi pemahaman atas tiga macam yaitu: pengubahan (translation), pemberian arti (interpretation), dan pembuatan ekstrapolasi (extrapolation). Dalam pembelajaran misalnya seseorang telah mampu mengubah (translation) ke dalam simbol-simbol dan sebaliknya, mampu mengartikan (interpretation) suatu kesamaan dan mampu memperkirakan (ekstrapolasi) suatu kecenderungan dalam kajian teori. ${ }^{35}$

Jika di kaitkan dengan Taksonomi Bloom maka pemahaman dalam pembelajaran meliputi menghafal, merumuskan, membuat simbol dan mengubah suatu bentuk ke bentuk lain. Aspek kognitif pemahaman dapat di hubungkan dengan pandangan pembelajaran sebagai bahasa yaitu bahasa simbol. Dengan adanya bahasa simbol dalam pembelajaran memudahkan pemakai untuk berkomunikasi, misalnya penyelesaian

${ }^{35}$ Ruseffendi, E.T,Pengantar kepada Membantu Guru Mengembangkan Kompetensinya dalam Pengajaran Pendidikan untuk Meningkatkan CBSA. (Bandung: Tarsito, 1991), h.221. 


\section{INTIQAD: JURNAL AGAMA DAN PENDIDIKAN ISLAM}

ISSN 1979-9950 (print) || ISSN 2598-0033 (online), http://jurnal.umsu.ac.id/index.php/intiqad DOI: https://doi.org/10.30596/intiqad.v10i1.1925

Published June 2018

soal cerita akan lebih mudah menggunakan praktik langsung dan kajian secara langsung. ${ }^{36}$

Polya dalam Sumarmo, mengemukakan empat tingkat pemahaman suatu hukum, yaitu pemahaman mekanikal, pemahaman induktuf, pemahaman rasional, dan pemahaman intuitif. Seseorang di katakan memiliki pemahaman mekanikal suatu hukum, jika ia dapat mengingat dan menerapkan hukum itu secara benar. Kemudian seseorang di katakan telah memiliki pemahaman induktif suatu hukum, jika ia telah mencobakan hukum itu berlaku dalam kasus sederhana dan yakin bahwa hukum itu berlaku dalam kasus serupa. Selanjutnya seseorang di katakan telah memiliki pemahaman rasional suatu hukum, bila ia dapat membuktikannya, dan seseorang di katakan telah memiliki pemahaman intuitif, jika ia telah yakin akan kebenaran hukum itu tanpa raguragu. ${ }^{37}$

\section{Metode Penelitian}

Pada prinsipnya ada dua jenis penelitian, yaitu penelitian kuantitatif

\footnotetext{
${ }^{36}$ Ruseffendi, E.T,...., h.222.

${ }^{37}$ Sumarmo, U,...., h.23.
}

dan penelitian kualitatif. Menurut Malau dalam Nofisaky penelitian kuantitatif merujuk pada anggapan bahwa suatu gejala sosial dapat di ukur dan di ubah dalam bentuk angka, sehingga dapat di lakukan perhitungan statistik untuk menganalisis data baik untuk keperluan deskriptif maupun untuk uji hipotesis, dan membuat kesimpulan. $^{38}$ Sedangkan menurut Bogman dan Taylor dalam Hapsari, penelitian kualitatif adalah sebagai prosedur penelitian yang menghasilkan data deskriptif berupa kata-kata tertulis atau lisan dari orang-orang dan perilaku yang di amati, menurut mereka kita tidak boleh mengisolasi individu atau organisasi ke dalam variabel atau hipotesis, tetapi perlu memandang sebagai bagian keutuhan. ${ }^{39}$

Penelitian ini adalah penelitian kualitatif dengan pendekatan eksperimen semu, bertujuan utama untuk menelaah hasil belajar dan

${ }^{38}$ Nofisaky, Metodologi Penelitian : Kuantitatif, Kualitatif, Tindakan Kelas, Pengembangan, dan Gabungan, (Jakarta: Angkasa Raya Press, 2016), h.41.

39 Hapsari, P.A, Metodologi Penelitian Kualitatif: Teori dan Praktik, (Semarang: Insan Cita Persada, 2015), h.33. 


\section{INTIQAD: JURNAL AGAMA DAN PENDIDIKAN ISLAM}

ISSN 1979-9950 (print) || ISSN 2598-0033 (online), http://jurnal.umsu.ac.id/index.php/intiqad DOI: https://doi.org/10.30596/intiqad.v10i1.1925

Published June 2018

pemahaman setelah siswa mendapatkan pengelolaan kelas.

Penelitian ini dilakukan di Madrasah Tsanawiyah Negeri 2 Medan, yang berada di Peratun No.3. Penelitian ini di laksanakan pada kelas VII yang pelaksanaannya berlangsung pada bulan Desember s/d Januari tahun 2018 selama 8 kali pertemuan (16 jam pelajaran $=16 \times 40$ menit) untuk masing-masing kelas sampel. Adapun alasan pemilihan lokasi penelitian ini karena penelitian yang sejenis belum pernah di laksanakan di sekolah tersebut. Selanjutnya pembelajaran Quran Hadis di Madrasah Tsanawiyah Negeri 2 Medan selama ini masih pembelajaran biasa dengan pendekatan di dominasi guru, siswa pasif dan selalu menunggu perintah guru, interaksi siswa dengan siswa maupun guru jarang terjadi. Kemudian sekolah tersebut memiliki kategori akreditasi A (Amat Baik).

Sampel penelitian di pilih dua kelas secara acak (cluster random sampling). Tahap pemilihan secara acak di mungkinkan karena berdasarkan informasi dari kepala sekolah dan dan guru pendistribusian siswa pada tiap kelas merata secara heterogen. Hal ini sesuai dengan pendapat Russefendi, salah satu cara memilih sampel mewakilinya populasinya adalah cara random sederhana, yaitu bila setiap anggota dari populasi mempunyai kesempatan yang sama untuk di pilih. Sehingga pemilihan sampel dalam penelitian ini adalah dengan penomoran tiap kelas pada kertas lalu dilakukan undian. $^{40}$ Sampel yang terpilih dua kelas yaitu kelas $\mathrm{VII}^{1}$ dan $\mathrm{VII}^{2}$ kemudian di lakukan undian untuk memilih kelompok pengelolaan kelas yaitu kelas VII $^{1}$, dan terpilih kelas pembelajaran konvensional yaitu $\mathrm{VII}^{2}$.

\section{Hasil Penelitian dan}

\section{Pembahasan}

Pengujian perbedaan rata-rata data hasil pretes dengan menggunakan statistik parametrik yaitu uji- $t$ pada taraf signifikansi $\alpha=0,05$ (uji dua pihak, $1 / 2 \alpha=0,025)$ dengan kriteria pengujian : $\mathrm{H}_{0}$ di terima, jika $-\mathrm{t}_{\text {tabel }}<\mathrm{t}_{\text {hitung }}<+\mathrm{t}_{\text {tabel }}$ , sedangkan pada keadaan lain $\mathrm{H}_{0}$ di tolak. Berdasarkan hasil perhitungan di peroleh untuk aspek pemahaman Quran Hadis $t_{\text {hitung }}=-0,381$ dan $t_{\text {tabel }}=1,990$,

40 Ruseffendi, E.T, Dasar-Dasar Penelitian Pendidikan dan Bidang Non Eksakta Lainnya, (Semarang: IKIP Semarang Press, 1998), h.78. 


\section{INTIQAD: JURNAL AGAMA DAN PENDIDIKAN ISLAM}

ISSN 1979-9950 (print) || ISSN 2598-0033 (online), http://jurnal.umsu.ac.id/index.php/intiqad DOI: https://doi.org/10.30596/intiqad.v10i1.1925

Published June 2018

karena $-t_{\text {tabel }}<t_{\text {hitung }}<+t_{\text {tabel }}$ maka $\mathrm{H}_{0}$ di terima. Sedangkan untuk aspek kemampuan hasil belajar di peroleh hasil thitung $=3,599$ karena $-t_{\text {hitung }}<-t_{\text {tabel }}$ atau $t_{\text {hitung }}>\mathrm{t}_{\text {tabel }}$ maka $\mathrm{H}_{0}$ ditolak atau $\mathrm{H}_{\mathrm{a}}$ di terima. Adapun hasil perhitungannya adalah sebagai berikut.
Karena $t_{\text {hitung }}>-t_{\text {tabel }}$ atau

$t_{\text {hitung }}<\mathrm{t}_{\text {tabel}}$, yaitu $-0,381>-1,99$

maka $\mathrm{H}_{0}$ di terima. Jadi, skor pretes pemahaman Quran Hadis kelas eksperimen dan kelas kontrol tidak terdapat perbedaan rata-rata. Secara lengkap di perlihatkan pada tabel sebagai berikut.

Tabel 1.

Uji Perbedaan Rata-Rata Pretes Kelas Eksperimen dan Kelas Kontrol

\begin{tabular}{|l|l|l|l|l|l|l|l|l|l|}
\hline \multirow{2}{*}{ Aspek } & \multicolumn{3}{|c|}{ Kelas eksperimen } & \multicolumn{3}{|c|}{ Kelas kontrol } & \multirow{2}{*}{$\mathbf{t}_{\text {hitung }}$} & $\mathbf{t}_{\text {tabel }}$ & Kesimpulan \\
\cline { 2 - 8 } & $\overline{\mathrm{x}}_{\mathrm{e}}$ & $\mathbf{S}_{\mathrm{e}}$ & $S_{e}^{2}$ & $\overline{\mathrm{x}}_{\mathrm{k}}$ & $\mathbf{S}_{\mathbf{k}}$ & $S_{k}^{2}$ & & & \\
\hline Pemahaman & 6,55 & 1,52 & 2,31 & 6,68 & 1,53 & 2,34 & 0,38 & 1,99 & $\begin{array}{l}\text { Tidak ada } \\
\text { perbedaan }\end{array}$ \\
\hline $\begin{array}{l}\text { Hasil } \\
\text { Belajar }\end{array}$ & 6,00 & 1,45 & 2,10 & 4,78 & 1,59 & 2,53 & 3,60 & 1,99 & $\begin{array}{l}\text { Terdapat } \\
\text { perbedaan }\end{array}$ \\
\hline
\end{tabular}

Dari tabel 1, terlihat bahwa pada aspek pemahaman $t_{\text {hitung }}<t_{\text {tabel, }}$ sedang pada aspek hasil belajar thitung $>$ tabel, dengan demikian di simpulkan bahwa data pretes kelas eksperimen dan kelas kontrol untuk aspek pemahaman Quran Hadis tidak terdapat perbedaan rata-rata yang signifikan, sedangkan untuk aspek hasil belajar terdapat perbedaan ratarata yang signifikan.

$$
\text { Selanjutnya di lakukan uji }
$$
perbedaan rata-rata antara kelas eksperimen dan kelas kontrol dengan menggunakan uji-t’ (uji t aksen) pada taraf signifikansi $\alpha=0,05$ dengan kriteria : terima $\mathrm{H}_{0,}$ jika $t_{\text {hitung }} \leq t_{\text {tabel, }}$, pada keadaan lain tolak $\mathrm{H}_{0}$. Hipotesis yang di uji pada penelitian ini adalah sebagai berikut.

$$
\begin{aligned}
& \text { Karena } t_{\text {hitung }}<-t_{\text {tabel }} \text { atau } \\
& t_{\text {hitung }}>\mathrm{t}_{\text {tabel }} \text {, yaitu }-3,975<-1,99 \\
& \text { maka } \mathrm{H}_{0} \text { di tolak atau } \mathrm{H}_{\mathrm{a}} \text { di terima. } \\
& \text { Jadi, skor postes pemahaman Quran } \\
& \text { Hadis kelas eksperimen dan kelas } \\
& \text { kontrol terdapat perbedaan rata- } \\
& \text { rata. }
\end{aligned}
$$




\section{INTIQAD: JURNAL AGAMA DAN PENDIDIKAN ISLAM}

ISSN 1979-9950 (print) || ISSN 2598-0033 (online), http://jurnal.umsu.ac.id/index.php/intiqad DOI: https://doi.org/10.30596/intiqad.v10i1.1925

Published June 2018

Tabel 2.

Uji Perbedaan Rata-rata Tes Pemahaman Kelas Eksperimen dan Kelas Kontrol

\begin{tabular}{|c|c|c|c|c|c|c|c|c|c|}
\hline \multirow{2}{*}{ Aspek } & \multicolumn{3}{|c|}{ Kelas eksperimen } & \multicolumn{3}{|c|}{ Kelas kontrol } & $\mathbf{t}_{\text {hitung }}$ & $\mathbf{t}_{\text {tabel }}$ & Kesimpulan \\
\cline { 2 - 6 } & $\overline{\mathrm{x}}_{\mathrm{e}}$ & $\mathrm{S}_{\mathrm{e}}$ & $S_{e}^{2}$ & $\overline{\mathrm{x}}_{\mathrm{k}}$ & $\mathrm{S}_{\mathrm{k}}$ & $S_{k}^{2}$ & & & \\
\hline $\begin{array}{c}\text { Pemahaman } \\
\text { Quran } \\
\text { Hadis }\end{array}$ & 14,63 & 1,25 & 1,562 & 13,33 & 1,65 & 2,722 & 3,975 & 1,99 & Lebih Baik \\
\hline
\end{tabular}

Dari tabel 2. di atas terlihat

pendekatan pengelolaan kelas dan siswa $t_{\text {hitung }}=3,975>t_{\text {tabel }}=1,99$, dengan yang mengikuti pembelajaran biasa demikian $\mathrm{H}_{0}$ di tolak atau $\mathrm{H}_{\mathrm{a}}$ di terima, adalah dengan menghitung gain kedua sehingga di simpulkan bahwa kelas dengan menggunakan rumus gain pemahaman Quran Hadis siswa yang ternormalisasi. Hasil perhitungan gain memperoleh pembelajaran dengan ternormalisasi disajikan pada tabel 4.16. pendekatan pengelolaan kelas lebih baik berikut,

dari siswa yang memperoleh pembelajaran biasa.

Untuk melihat peningkatan pemahaman siswa dalam Quran Hadis yang mengikuti pembelajaran dengan

Tabel 3.

Gain Ternormalisasi Tes Pemahamanan Kelas Eksperimen dan Kelas Kontrol

\begin{tabular}{|c|c|c|c|c|}
\hline \multirow{2}{*}{ Aspek } & \multicolumn{2}{|c|}{ Kelas Eksperimen } & \multicolumn{2}{c|}{ Kelas Kontrol } \\
\cline { 2 - 5 } & $\begin{array}{l}\text { Rata-rata gain } \\
\text { ternormalisasi }\end{array}$ & Kategori & $\begin{array}{c}\text { Rata-rata gain } \\
\text { ternormalisasi }\end{array}$ & Kategori \\
\hline $\begin{array}{l}\text { Pemahaman } \\
\text { Quran Hadis }\end{array}$ & 0,600 & Sedang & 0,494 & Sedang \\
\hline
\end{tabular}

gain ternormalisasi pemahaman Quran

Hadis siswa kelas eksperimen lebih besar daripada kelas kontrol, namun gain kedua kelas tersebut berada pada kategori sedang. Selanjutnya di lakukan ternormalisasi terhadap pemahaman

Quran Hadis siswa antara kelas eksperimen dengan kelas kontrol dengan menggunakan uji-t' (uji t aksen) pada taraf signifikansi $\alpha=0,05$. 


\section{INTIQAD: JURNAL AGAMA DAN PENDIDIKAN ISLAM}

ISSN 1979-9950 (print) || ISSN 2598-0033 (online), http://jurnal.umsu.ac.id/index.php/intiqad DOI: https://doi.org/10.30596/intiqad.v10i1.1925

Published June 2018

Karena $t_{\text {hitung }}<-t_{\text {tabel }}$ atau

$t_{\text {hitung }}>\mathrm{t}_{\text {tabel}}$, yaitu $-5,30<-1,99$ maka

$\mathrm{H}_{0}$ di tolak atau $\mathrm{H}_{\mathrm{a}}$ di terima. Jadi, skor gain ternormalisasi pemahaman Quran
Hadis kelas eksperimen dan kelas kontrol terdapat perbedaan rata-rata.

Seperti tampak pada tabel 4. sebagai berikut.

Tabel 4.Uji Perbedaan Rata-rata Gain Ternormalisasi Tes Pemahaman Kelas Eksperimen dan Kelas Kontrol

\begin{tabular}{|c|c|c|c|c|c|c|c|c|c|}
\hline \multirow{2}{*}{ Aspek } & \multicolumn{3}{|c|}{ Kelas eksperimen } & \multicolumn{3}{|c|}{ Kelas kontrol } & $\mathbf{t}_{\text {hitun }}$ & $\mathbf{t}_{\text {tabel }}$ & Kesimpula \\
\cline { 2 - 7 } & $\overline{\mathrm{x}}_{\mathrm{e}}$ & $\mathbf{S}_{\mathbf{e}}$ & $S_{e}^{2}$ & $\overline{\mathrm{x}}_{\mathrm{k}}$ & $\mathbf{S}_{\mathbf{k}}$ & $S_{k}^{2}$ & $\mathbf{g}$ & & $\mathbf{n}$ \\
\hline $\begin{array}{c}\text { Pemahama } \\
\mathrm{n}\end{array}$ & 0,60 & 0,08 & 0,00 & 0,49 & 0,11 & 0,01 & 5,30 & 1,9 & Lebih baik \\
$\begin{array}{c}\text { Quran } \\
\text { Hadis }\end{array}$ & 0 & 5 & 7 & 4 & 4 & 3 & & 9 & \\
\hline
\end{tabular}

Berdasarkan hasil pengujian pada tabel $4.17 \mathrm{di}$ atas di peroleh $t_{\text {hitung }}=5,30$ $\geq t_{\text {tabel }}=1,99$, dengan demikian $\mathrm{H}_{0}$ di tolak atau $\mathrm{H}_{\mathrm{a}}$ di terima sehingga di simpulkan bahwa gain kelas eksperimen lebih baik daripada kelas kontrol atau pada siswa yang mengikuti pembelajaran dengan pendekatan pengelolaan kelas terjadi peningkatan yang lebih baik pada pemahaman Quran Hadis daripada siswa yang mengikuti pembelajaran biasa.

Tabel 5. Uji Perbedaan Rata-rata Tes Kemampuan Hasil Belajar Kelas Eksperimen dan Kelas Kontrol

\begin{tabular}{|c|c|c|c|c|c|c|c|c|c|}
\hline \multirow{2}{*}{ Aspek } & \multicolumn{3}{|c|}{ Kelas eksperimen } & \multicolumn{3}{|c|}{ Kelas kontrol } & $\mathbf{t}_{\text {hitung }}$ & $\mathbf{t}_{\text {tabel }}$ & Kesimpulan \\
\cline { 2 - 8 } & $\overline{\mathrm{x}}_{\mathrm{e}}$ & $\mathbf{S}_{\mathbf{e}}$ & $S_{e}^{2}$ & $\overline{\mathrm{x}}_{\mathrm{k}}$ & $\mathbf{S}_{\mathbf{k}}$ & $S_{k}^{2}$ & & & \\
\hline $\begin{array}{c}\text { Kemampuan } \\
\begin{array}{c}\text { Hasil } \\
\text { Belajar }\end{array}\end{array}$ & 17,23 & 2,98 & 8.88 & 9,70 & 3,89 & 15,13 & 9,72 & 1,99 & Lebih baik \\
\hline
\end{tabular}

Dari tabel 4.18. di atas terlihat $\mathrm{t}_{\text {hitung }}=9,72>\mathrm{t}_{\text {tabel }}=1,99$, dengan demikian $\mathrm{H}_{0}$ di tolak atau $\mathrm{H}_{\mathrm{a}}$ di terima, $>t_{\text {tabel}}$, yaitu $-12,54<-1,98$ maka $\mathrm{H}_{0}$ di tolak atau $\mathrm{H}_{\mathrm{a}}$ di terima. Jadi, skor postes kemampuan hasil belajar kelas eksperimen dan kelas kontrol terdapat perbedaan rata-rata. Secara ringkas hasil dari perhitungan uji perbedaan rata-rata dapat di lihat pada tabel 5 . sebagai berikut. 


\section{INTIQAD: JURNAL AGAMA DAN PENDIDIKAN ISLAM}

ISSN 1979-9950 (print) || ISSN 2598-0033 (online), http://jurnal.umsu.ac.id/index.php/intiqad DOI: https://doi.org/10.30596/intiqad.v10i1.1925

Published June 2018

pengelolaan kelas lebih baik dari siswa yang memperoleh pembelajaran biasa.

Untuk melihat peningkatan kemampuan hasil belajar siswa dalam Quran Hadis yang mengikuti pembelajaran dengan pendekatan pengelolaan kelas dan siswa yang

Tabel 6. Gain Ternormalisasi Tes Kemampuan Hasil Belajar Kelas Eksperimen dan Kelas Kontrol

\begin{tabular}{|c|c|c|c|c|}
\hline \multirow{2}{*}{ Aspek } & \multicolumn{2}{|c|}{ Kelas Eksperimen } & \multicolumn{2}{c|}{ Kelas Kontrol } \\
\cline { 2 - 5 } & $\begin{array}{l}\text { Rata-rata gain } \\
\text { ternormalisasi }\end{array}$ & Kategori & $\begin{array}{c}\text { Rata-rata gain } \\
\text { ternormalisasi }\end{array}$ & Kategori \\
\hline $\begin{array}{c}\text { Kemampuan } \\
\text { Hasil Belajar }\end{array}$ & 0,622 & Sedang & 0,252 & Rendah \\
\hline
\end{tabular}

Dari tabel 6. terlihat bahwa gain ternormalisasi kemampuan hasil belajar siswa kelas eksperimen lebih besar daripada kelas kontrol.

Temuan hasil penelitian berikut adalah berdasarkan analisis data dan temuan-temuan di lapangan. Selanjutnya untuk memberikan kontribusi ke arah perbaikan jika menerapkan model pembelajaran ini di sekolah, perlu di kemukakan hal-hal positif yang menunjang keberhasilan dan hambatan-hambatan yang di temukan pada eksperimen tentang pembelajaran dengan pendekatan pengelolaan kelas, selengkapnya di uraikan dalam pembahasan berikut ini.

\section{Pemahaman Quran Hadis dan} Kemampuan Hasil Belajar Siswa mengikuti pembelajaran biasa adalah dengan menghitung gain kedua kelas dengan menggunakan rumus gain ternormalisasi. Hasil perhitungan gain ternormalisasi disajikan pada tabel 6 . sebagai berikut.
Berdasarkan analisis terhadap skor rata-rata pretes pada kelompok siswa yang memperoleh pembelajaran dengan pendekatan pengelolaan kelas (kelas eksperimen) di peroleh rata-rata skor pretes pemahaman Quran Hadis sebesar 6,55, dengan deviasi standar 1,51, kemampuan hasil belajar sebesar 6,00, dengan deviasi standar 1,45. Sedangkan pada kelompok siswa yang memperoleh pembelajaran biasa/konvensional (kelas kontrol) di peroleh skor rata-rata pretes pemahaman Quran Hadis sebesar 6,68, dengan deviasi standar 1,53, kemampuan hasil belajar sebesar 4,78, dengan deviasi standar 1,58. Dari hasil pengujian data rata-rata skor pretes terhadap kedua kelompok dapat di 


\section{INTIQAD: JURNAL AGAMA DAN PENDIDIKAN ISLAM}

ISSN 1979-9950 (print) || ISSN 2598-0033 (online), http://jurnal.umsu.ac.id/index.php/intiqad DOI: https://doi.org/10.30596/intiqad.v10i1.1925

Published June 2018

simpulkan bahwa kedua kelompok memiliki kemampuan awal yang sama atau tidak terdapat perbedaan yang signifikan. Hal ini sesuai dengan salah satu karakteristik penelitian eksperimen yang di kemukakan oleh Ruseffendi, bahwa ekivalensi subjek dalam kelompok-kelompok yang berbeda perlu ada, agar bila ada hasil berbeda yang di peroleh kelompok, itu bukan di sebabkan karena tidak ekivalennya kelompok-kelompok itu, tetapi karena adanya perlakuan. Sehingga dapat di simpulkan bahwa kedua kelompok siap untuk menerima materi baru. ${ }^{41}$

Setelah di lakukan pembelajaran sebanyak enam kali pertemuan pada kedua kelompok dengan pendekatan yang berbeda, selanjutnya di berikan postes untuk mengetahui pemahaman Quran Hadis dan kemampuan hasil belajar siswa. Kemudian di lakukan analisis terhadap data postes dan data gain kedua kelompok (kelas eksperimen dan kelas kontrol). Skor postes pemahaman Quran Hadis pada kelas eksperimen atau pada kelas yang

41 Ruseffendi, E.T, Dasar-Dasar Penelitian Pendidikan dan Bidang NonEksakta Lainnya. (Semarang: IKIP Semarang Pres, 2001), h.39. menggunakan pembelajaran dengan pendekatan pengelolaan kelas di peroleh rata-rata 14,63 $(73,15 \%)$ dengan deviasi standar 1,25, dan kemampuan hasil belajar di peroleh rata-rata 17,23 $(71,79 \%)$ dengan deviasi standar 2,98. Sedang pada kelas kontrol di peroleh skor rata-rata pemahaman Quran Hadis $13,32(66,60 \%)$ dengan deviasi standar 1,65 dan kemampuan hasil belajar 9.7 $(40,41 \%)$ dengan deviasi standar 3,89. Dari rata-rata skor yang di peroleh tersebut, untuk pemahaman Quran Hadis kedua kelas di klasifikasikan sedang karena rata-rata masing-masing kelas di atas $60 \%$ dari skor ideal, untuk kemampuan hasil belajar kelas eksperimen di klasifikasikan sedang dan kelas kontrol di klasifikasikan rendah.

Dari hasil analisis terhadap perbedaan rata-rata skor tes pemahaman Quran Hadis pada kelas eksperimen dan kelas kontrol dapat di simpulkan bahwa rata-rata skor tes pemahaman Quran Hadis kelas eksperimen lebih baik daripada rata-rata skor tes pemahaman Quran Hadis kelas kontrol pada taraf signifikansi 5\%. Begitu pula hasil analisis terhadap perbedaan rata-rata skor tes kemampuan hasil belajar, dapat di simpulkan bahwa rata-rata skor tes 


\section{INTIQAD: JURNAL AGAMA DAN PENDIDIKAN ISLAM}

ISSN 1979-9950 (print) || ISSN 2598-0033 (online), http://jurnal.umsu.ac.id/index.php/intiqad DOI: https://doi.org/10.30596/intiqad.v10i1.1925

Published June 2018

kemampuan hasil belajar kelas

eksperimen lebih baik daripada rata-rata skor tes kemampuan hasil belajar kelas kontrol. Kedua kelas ternyata mengalami peningkatan kemampuan dalam menyelesaikan soal-soal yang di berikan, baik pada pemahaman Quran Hadis maupun kemampuan hasil belajar. Namun peningkatan yang terjadi pada kelas eksperimen lebih besar daripada kelas kontrol. Hal ini menunjukan bahwa kelompok eksperimen memiliki kemampuan yang lebih baik dalam menyelesaikan soal yang di berikan.

Berdasarkan hasil analisis secara kuantitatif terlihat bahwa adanya keterkaitan antara pemahaman Quran Hadis dengan kemampuan hasil belajar baik pada kelas kontrol maupun pada kelas eksperimen. Besarnya koefisien korelasi pada kelas kontrol sebesar 0,301 sedang pada kelas eksperimen 0,475 . Apabila di bandingkan dengan $r_{\text {tabel }}$ dengan $\mathrm{n}=40$ dengan taraf signifikansi $\alpha=0,05$ di peroleh $r_{\text {tabel }}=$ 0,257, maka di simpulkan bahwa terdapat korelasi antara pemahaman Quran Hadis dengan kemampuan hasil belajar siswa.

\section{Sikap Siswa terhadap}

Pembelajaran dengan Pendekatan

\section{Pengelolaan Kelas}

Berdasarkan respons siswa yang di ungkapkan lewat skala sikap yang di berikan kepada siswa, secara umum respon siswa terhadap pembelajaran Quran Hadis memiliki sikap yang positif. Hal ini secara jelas dapat di lihat dari skor sikap yaitu sekitar 3,44 lebih besar dari skor sikap netral yaitu 2,77, ini tidak terlepas dari teknik dan cara guru dalam menyajikan serta mengemas materi pelajaran kepada siswa. Demikian juga sikap siswa terhadap pembelajaran dengan pendekatan pengelolaan kelas, terhadap pelajaran Quran Hadis, dan soal-soal yang di berikan.

Berdasarkan hasil jawaban siswa baik terhadap soal-soal yang di berikan, maupun soal postes, terlihat bahwa siswa memiliki antusiasme dan semangat yang tinggi terhadap pembelajaran yang di kembangkan. Sehingga para siswa lebih rajin dalam belajar dan mau bekerja keras terhadap soal-soal yang di berikan oleh guru, walaupun mereka belum mencapai hasil yang di harapkan. 


\section{INTIQAD: JURNAL AGAMA DAN PENDIDIKAN ISLAM}

ISSN 1979-9950 (print) || ISSN 2598-0033 (online), http://jurnal.umsu.ac.id/index.php/intiqad DOI: https://doi.org/10.30596/intiqad.v10i1.1925

Published June 2018

\section{Aktifitas Siswa Selama bahwa guru berusaha menggali}

\section{Pembelajaran dengan Pendekatan}

\section{Pengelolaan Kelas}

Berdasarkan hasil observasi siswa terhadap kelas yang memperoleh pembelajaran dengan pendekatan pengelolaan kelas, di peroleh temuan bahwa sikap siswa lebih aktif. Aktifitas siswa membuat siswa menjadi lebih kreatif dan memiliki semangat yang tinggi dalam memecahkan masalah yang di berikan. Sejalan dengan hal ini Ruseffendi mengemukakan belajar aktif dapat menumbuhkan sikap kreatifnya di kemudian hari lebih berhasil. Maksudnya ialah lebih dapat mengatasi persoalan di masyarakat. Aktifitas siswa dalam memahami materi di lakukan dengan diskusi sesama teman kelompok dan bertanya kepada guru. ${ }^{42}$

Hasil observasi juga menemukan bahwa peranan guru mulai berkurang dalam pembelajaran. Guru berfungsi sebagai fasilitator, mengarahkan dan memotivasi siswa dalam belajar. Hal ini sesuai dengan pandangan kontruktivisme dan teori belajar Bruner

\footnotetext{
${ }^{42}$ Ruseffendi, E.T, Pengantar kepada Membantu Guru Mengembangkan Kompetensinya dalam Pengajaran Pendidikan untuk Meningkatkan CBSA. (Bandung: Tarsito, 1991), h.283.
}

pemahaman awal siswa dengan cara memberikan suatu permasalahan yang ada kaitannya dengan kehidupan seharihari pada awal pembelajaran. Peranan guru seperti ini dapat meningkatkan motivasi dan antusias siswa dalam belajar. Hal ini tampak dari aktifitas dan interaksi siswa dengan guru yang berkembang lebih baik dari pembelajaran sebelumnya. Peningkatan ini menunjukkan bahwa jika kepada siswa di berikan kesempatan untuk lebih aktif dalam belajar maka siswa mempunyai kesempatan untuk mengembangkan pengetahuannya. Hal ini sejalan dengan pernyataan Horsley dalam Bahri, bahwa pemberian kesempatan kepada siswa yang lebih luas akan lebih bermanfaat karena mereka senantiasa membangun pengetahuan dan kemampuannya sendiri. ${ }^{43}$

\section{E. Simpulan dan Saran}

\section{Simpulan}

Berdasarkan hasil deskripsi data, uji persyaratan analisis, hasil penelitian,

${ }^{43}$ Bahri, S, Penerapan Pembelajaran Kooperatif dengan Pemberian Bahan Ajar Quran Hadis. (Tesis Magister pada PPS Universitas Islam Negeri Sunan Gunung Djati: tidak diterbitkan, 2003), h.56. 


\section{INTIQAD: JURNAL AGAMA DAN PENDIDIKAN ISLAM}

ISSN 1979-9950 (print) || ISSN 2598-0033 (online), http://jurnal.umsu.ac.id/index.php/intiqad DOI: https://doi.org/10.30596/intiqad.v10i1.1925

Published June 2018

temuan penelitian dan keterbatasan penelitian selama menggunakan pengelolaan kelas dengan menekankan pada kemampuan pemahaman dan hasil belajar maka peneliti memperoleh kesimpulan sebagai berikut :

1. Siswa kelas VII Madrasah Tsanawiyah Negeri 2 Medan yang memperoleh pembelajaran dengan pendekatan pengelolaan kelas menunjukan pemahaman Quran Hadis secara signifikan lebih baik di bandingkan dengan siswa yang memperoleh pembelajaran secara biasa. Hal ini terlihat dari skor ratarata pemahaman Quran Hadis di kedua kelas, walaupun keduanya dalam kualifikasi sedang.

2. Hasil Belajar siswa kelas VII Madrasah Tsanawiyah Negeri 2 Medan yang memperoleh pembelajaran dengan pendekatan pengelolaan kelas menunjukan secara signifikan lebih baik di bandingkan dengan siswa yang memperoleh pembelajaran secara biasa. Hal ini terlihat dari rata-rata kemampuan hasil belajar siswa yang memperoleh pembelajaran dengan pendekatan pengelolaan kelas berada pada kualifikasi sedang, sedangkan rata-rata kemampuan hasil belajar siswa yang memperoleh pembelajaran biasa berada pada kualifikasi kurang.

3. Terdapat korelasi yang positif antara pemahaman Quran Hadis dengan kemampuan hasil belajar siswa. Pada kelas kelompok eksperimen di peroleh hasil bahwa korelasi pemahaman Quran Hadis terhadap kemampuan hasil belajar siswa lebih besar di bandingkan dengan kelas kelompok kontrol.

4. Sikap siswa terhadap pelajaran Quran Hadis, pembelajaran dengan pendekatan pengelolaan kelas dan terhadap soal pemahaman Quran Hadis dan kemampuan hasil belajar adalah positif. Pembelajaran ini juga membuat siswa lebih antusias dan semangat belajarnya meningkat, tumbuhnya sikap percaya diri dan keberanian dalam berkomunikasi.

5. Aktifitas siswa yang memperoleh pembelajaran dengan pendekatan pengelolaan kelas lebih aktif dalam belajar, terutama berdiskusi dengan temannya, dan juga siswa lebih berani mengemukakan atau 


\section{INTIQAD: JURNAL AGAMA DAN PENDIDIKAN ISLAM}

ISSN 1979-9950 (print) || ISSN 2598-0033 (online), http://jurnal.umsu.ac.id/index.php/intiqad DOI: https://doi.org/10.30596/intiqad.v10i1.1925

Published June 2018

mengajukan pertanyaaan kepada

guru, serta lebih kreatif dalam

menyelesaikan permasalahan yang

di berikan.

\section{Saran}

Penelitian tentang pengelolaan kelas terhadap kemampuan pemahaman dan hasil belajar adalah merupakan upaya guru dalam meningkatkan hasil belajar siswa. Berdasarkan hasil penelitian ini, pembelajaran Quran Hadis dengan pengelolaan kelas baik di kembangkan terhadap kemampuan pemahaman dan hasil belajar dalam proses pembelajaran Quran Hadis. Untuk itu peneliti menyarankan beberapa hal berikut:

\section{Kepada Para Guru}

a. Pembelajaran dengan pendekatan pengelolaan kelas merupakan salah satu alternatif bagi guru Quran Hadis dalam menyajikan materi Quran Hadis.

b. Dalam menerapkan pembelajaran pendekatan pengelolaan kelas guru hendaknya membuat suatu skenario dan perencanaan yang matang, sehingga tidak banyak waktu yang terbuang oleh hal-hal yang tidak perlu khususnya menentukan materi yang di ajarkan, agar tidak terjadi miskonsepsi. c. Pembelajaran dengan pendekatan pengelolaan kelas hendak di terapkan pada materi yang esensial, karena menyita waktu yang relatif lama.

d. Dalam setiap pembelajaran, guru sebaiknya menciptakan suasana belajar yang lebih banyak memberikan kesempatan kepada siswa untuk mengungkapkan gagasan-gagasan Quran Hadis dalam bahasa dan cara mereka sendiri, sehingga dalam belajar Quran Hadis siswa menjadi lebih berani berargumentasi, lebih percaya diri, dan kreatif.

\section{Kepada Lembaga Terkait}

Pembelajaran dengan pendekatan pengelolaan kelas, masih sangat asing baik bagi guru maupun siswa, oleh karena itu perlu di sosialisasikan oleh sekolah dengan harapan dapat meningkatkan kemampuan hasil belajar siswa, khususnya meningkatkan pemahaman dan kemampuan hasil belajar siswa, yang tentunya akan berimplikasi pada meningkatnya hasil siswa dalam penguasaan materi Quran Hadis. 


\section{INTIQAD: JURNAL AGAMA DAN PENDIDIKAN ISLAM}

ISSN 1979-9950 (print) || ISSN 2598-0033 (online), http://jurnal.umsu.ac.id/index.php/intiqad DOI: https://doi.org/10.30596/intiqad.v10i1.1925

Published June 2018

\section{Kepada Para Peneliti}

Untuk penelitian lebih lanjut hendaknya penelitian ini dapat di lengkapi dengan meneliti aspek lain secara lebih terperinci yang belum terjangkau oleh penulis saat ini.

\section{Daftar Pustaka}

Ahmadi, A. dan Supriyono, W. (1990). Psikologi Belajar. Jakarta: Rineka Cipta.

Arikunto, S. (2002). Prosedur Penelitian Suatu Pendekatan Praktek. Edisi Revisi V. Jakarta: Rineka Cipta.

Bagaskara, S. (2016). Hubungan Pengelolaan Kelas dan Motivasi Belajar Akidah Akhlak Terhadap Kemampuan Intelegensi Siswa X Madrasah Aliyah Negeri 5 Jawa Tengah. Semarang: Universitas Islam Negeri Sunan Kalijaga, Tesis tidak di terbitkan.

Budiningsih, C. A. (2002). Belajar dan Pembelajaran. Yogyakarta: Fakultas Ilmu Pendidikan Universitas Negeri Yogyakarta.

Departemen Pendidikan Nasional. (2003). Materi Pelatihan Peningkatan Kemampuan Guru dalam Penyusunan dan
Penggunaan Alat Evaluasi. Jakarta: Direktorat Pendidikan Lanjutan Pertama.

Djamarah, S.B. (1994a). Hasil Belajar dan Kompetensi Guru. Surabaya: Usaha Nasional.

Djamarah, S.B. (2009b). Hasil Belajar dan Kompetensi Guru. Surabaya: Usaha Nasional.

Djamarah, S.B. dan Zain, A. (2002). Strategi Belajar Mengajar. Jakarta: Rineka Cipta.

Feldmann, M.B. (2002). Classroom Managment. EDU658. [Online].

Fraenkel, J.R. dan Wallen, N.E. (1990). How to Design and Evaluate Research in Education. USA: Mc Graw-Hill Publishing Company.

Hapsari, P.A. (2015). Metodologi Penelitian Kualitatif: Teori dan Praktik. Semarang: Insan Cita Persada.

Hapsari, P.A. (2016). Pembelajaran : Teori dan Praktik. Yogyakarta: Mutiara Press.

Haryanto, dkk. (2003). Strategi Belajar Mengajar. Yogyakarta: Fakultas Ilmu Pendidikan Universitas Negeri Yogyakarta. 


\section{INTIQAD: JURNAL AGAMA DAN PENDIDIKAN ISLAM}

ISSN 1979-9950 (print) || ISSN 2598-0033 (online), http://jurnal.umsu.ac.id/index.php/intiqad DOI: https://doi.org/10.30596/intiqad.v10i1.1925

Published June 2018

Hasbullah. (1994). Pendidikan Dalam Keluarga. Jakarta: Rajawali Press.

Husna, R. (2013). Pengaruh Iklim Kelas dan Minat Belajar Terhadap Hasil Belajar Siswa Kelas VII SMP Negeri 1 Jakarta. Jakarta: Universitas Islam Negeri Syarif Hidayatullah, Tesis tidak diterbitkan.

Kartono. (1995). Proses Belajar Mengajar. Yogyakarta: Lembaga Penelitian Institut Keguruan dan Ilmu Pendidikan Yogyakarta.

Kementrian Agama. (2016). al Quran dan Terjemahan. Jakarta: Kementrian Agama Republik Indonesia.

Khairi, A. (2015a). Evaluasi Proses Pembelajaran MI, MTs, dan MA, Jakarta: Universitas Islam Negeri Syarif Hidayatullah.

Khairi, A. (2015b). Pengelolaan Kelas: Teori dan Praktik. Jakarta: Insan Ilmu Press.

Meltzer, D.E. (2002). The Relationship Between Preparation and Conceptual Learning Gain in Learning: A Possible "Hidden Variable" in Diagnostics Pretest Scores. Dalam
American Journal of Learning. [Online].

Muijs, D. dan Reynolds, D. (2008). Effective Teaching. Yogyakarta: Pustaka Pelajar.

Mulyani, W.T. (2001). Pengelolaan Kelas: Classroom Management. Yogyakarta: Fakultas Ilmu Pendidikan Universitas Negeri Yogyakarta.

Munandar, S.C.U. (1977). Classroom and Education. Disertasi Doktor, Universitas Indonesia. Jakarta: Departemen Pendidikan dan Kebudayaan.

Nofisaky. (2015). Pendidikan Agama Islam: Teori dan Praktik. Jakarta: Lentera Ilmu.

Nofisaky. (2016a). Evaluasi Pembelajaran: Teori dan Praktik. Bandung: Azalea.

Nofisaky. (2016b). Metodologi Penelitian: Kuantitatif, Kualitatif, Tindakan Kelas, Pengembangan, dan Gabungan. Jakarta: Angkasa Raya Press.

Nofisaky. (2016c). Pengelolaan Kelas: Teori dan Praktik. Jakarta: Universitas Negeri Jakarta. 


\section{INTIQAD: JURNAL AGAMA DAN PENDIDIKAN ISLAM}

ISSN 1979-9950 (print) || ISSN 2598-0033 (online), http://jurnal.umsu.ac.id/index.php/intiqad DOI: https://doi.org/10.30596/intiqad.v10i1.1925

Published June 2018

Nofisaky. (2016d). Psikologi Belajar:

Teori dan Praktik. Jakarta:

Universitas Islam Negeri

Syarif Hidayatullah.

Nofisaky. (2016e). Strategi Proses Pembelajaran. Bandung: Azalea.

Pehkonen, E (1997). "Classroom Managment". International Review on Learning Education. 29 (3).

Ratnaningsih, N. (2003). Mengembangkan Hasil Belajar Siswa Sekolah Menengah Umum Melalui Pengelolaan Kelas (Studi Eksperimen pada Siswa SMUN 1 Tasikmalaya). Tesis pada Universitas Islam Negeri Sunan Gunung Djati: Tidak diterbitkan.

Renata. (2016). Evaluasi Pembelajaran PAI. Jakarta: Mutiara Press.

Renata. (2016). Teori Belajar. Jakarta: Insan Press.

Ruseffendi, E.T. (1998). Dasar-Dasar Penelitian Pendidikan dan Bidang Non Eksakta Lainnya. Semarang: IKIP Semarang Press.

Ruseffendi, E.T. (1998). Statistika Dasar Untuk Penelitian Pendidikan. Bandung: IKIP Bandung Press.
Sari, Ulfa. (2016). Pengaruh Pengelolaan Kelas dan Lingkungan Belajar Fikih Terhadap Kemampuan Penalaran dan Kemampuan Komunikasi Siswa Kelas VII MTs Negeri 1 Jakarta. Jakarta: Universitas Islam Negeri Syarif Hidayatullah, Disertasi tidak di terbitkan.

Subino. (1997). Konstruksi dan Analisis Tes. Suatu Pengantar kepada Teori Tes dan Pengukuran, Jakarta: Depdikbud.

Slameto. (2003). Belajar dan FaktorFaktor Yang Mempengaruhinya. Edisi Revisi. Jakarta: PT Rineka Cipta.

Sudjana, N. (2005a). Dasar-Dasar Proses Belajar Mengajar. Bandung: Sinar Baru Aldesindo.

Sudjana, N. (2005b). Penilaian Hasil Proses Belajar Mengajar. Bandung: PT Remaja Rosdakarya.

Sudjana. (1992). Metoda Statistika. Bandung: Tarsito.

Sudjana. (2011). Metoda Statistika, Edisi Revisi Ke VI. Bandung: Tarsito. 


\section{INTIQAD: JURNAL AGAMA DAN PENDIDIKAN ISLAM}

ISSN 1979-9950 (print) || ISSN 2598-0033 (online), http://jurnal.umsu.ac.id/index.php/intiqad DOI: https://doi.org/10.30596/intiqad.v10i1.1925

Published June 2018

Suherman, E. dan Kusumah, Y.S. (1990). Petunjuk Praktis Untuk Melaksanakan Evaluasi Pendidikan. Bandung: Wijayakusumah.

Sukmadinata, N.S. (2005). Landasan Psikologi Proses Pendidikan, Bandung: PT Remaja Rosdakarya.

Sumantri, M. dan Permana, J. (1999). Strategi Belajar Mengajar. Yogyakarta: Dirjen Pendidikan Tinggi.

Susilowati dan Ali, A. (2011). Pengelolaan Kelas dalam PKR. Jakarta: Dirjen Pendidikan Tinggi.

Syafi'i, A. (2016). Belajar : Teori dan Praktik. Jakarta: Sinar Ilmu.

Syah, M. (1999). Psikologi Belajar. Jakarta: PT Raja Grafindo Persada.

Syah, Muhhibbin. (2010). Psikologi Pendidikan. Bandung: PT Remaja Rosdakarya.

Syauky, A. (2015). Pengaruh Pengelolaan Kelas dan Minat Belajar Quran Hadis Terhadap Hasil Belajar Siswa Kelas VII MTs Negeri 2 Jawa Barat T.A. 2014/2015. Bandung: Universitas Islam Negeri
Sunan Gunung Djati, Tesis tidak di terbitkan.

Usman, M.U. (2006). Menjadi Guru Profesional. Bandung: PT. Remaja Rosdakarya.

Zuhri, M. (2015). Pembelajaran di Kelas dalam Persepektif Sosial. Jakarta: CV Kenanga Indah. 